\title{
Agricultural Interventions to Enhance Climate Change Adaptation of Underutilized Root and Tuber Crops
}

\author{
Joseph P. Gweyi-Onyango, Michael Ajanja Sakha, and Joyce Jefwa
}

\section{Contents}

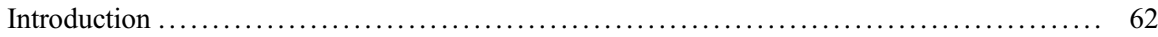

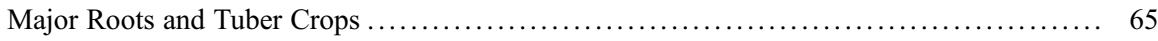

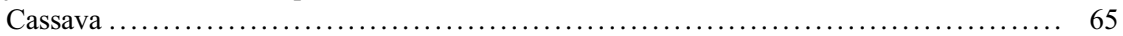

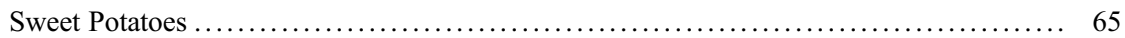

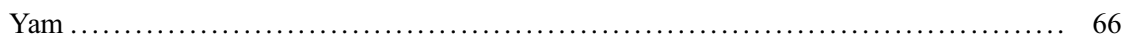

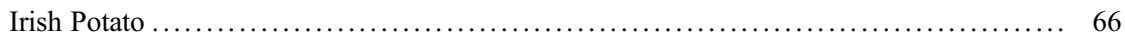

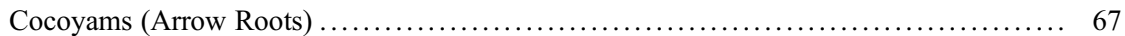

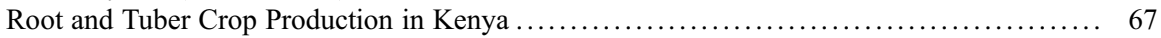

Agricultural Interventions for Adaptation to Climate Change ....................... 69

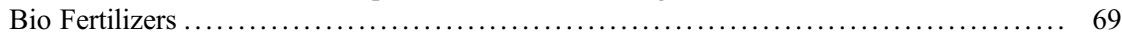

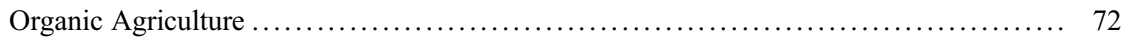

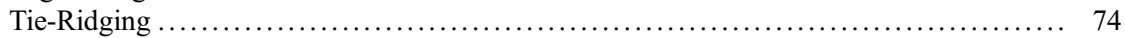

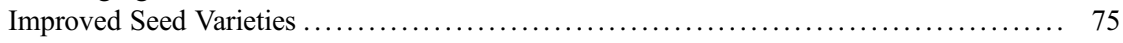

Management of Community Seed Banks $\ldots \ldots \ldots \ldots \ldots \ldots \ldots \ldots \ldots \ldots \ldots \ldots \ldots \ldots \ldots \ldots$

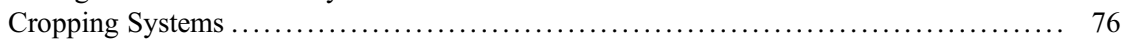

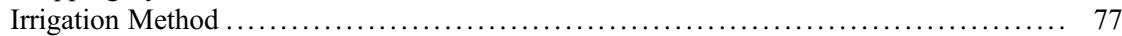

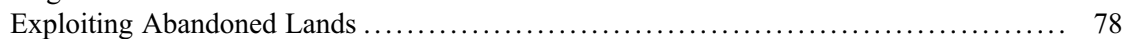

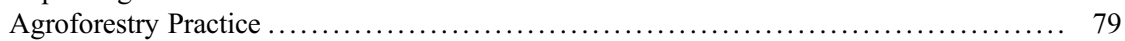

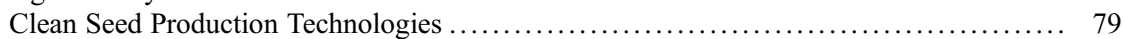

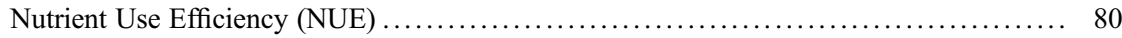

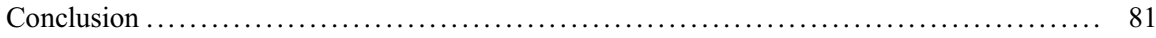

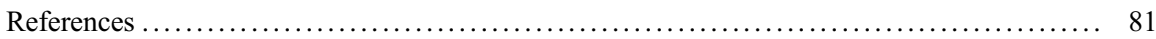

This chapter was previously published non-open access with exclusive rights reserved by the Publisher. It has been changed retrospectively to open access under a CC BY 4.0 license and the copyright holder is "The Author(s)". For further details, please see the license information at the end of the chapter.

\section{J. P. Gweyi-Onyango}

Department of Agricultural Science and Technology, Kenyatta University, Nairobi, Kenya

M. A. Sakha $(\bowtie) \cdot$ J. Jefwa

Botany Department, National Museums of Kenya, Nairobi, Kenya 


\section{Abstract}

Agricultural intensification worldwide is increasingly relying on a narrow range of crops such as rice, wheat, and maize. The reliability on this relatively small numbers of food diversities raises a very serious concern about the sustainability managing our nutrition today and in the future. We conducted a scoping review using online databases to identify various agricultural interventions that can be utilized for enhancement of underutilized root and tuber crops adaptability under the current observable effects of climate change. This is because reports of underutilized crops' adaptability to climate change continues to remain anecdotal with limited research capacity to support them. The results mooted a wide range of crop production techniques that can be utilized in production of root and tuber crops. They includes biofertilizers, tied ridging method, improved seed varieties, management of community seed banks, cropping systems, irrigation methods, exploiting abandoned lands, agroforestry practice, clean seed production technologies, and nutrient use efficiency. Based on the findings, each of these interventions plays different roles in management of the negative impacts brought up by climate change and thus they would be useful when adopted in combination since package adoption would enable farmers to benefit from the positive synergy of the selected interventions. The interventions are therefore recommended not only for sustainability but also for profitable production to meet feed, food, energy, and fiber needs and foster economic growth in the ever changing world. Therefore this chapter contributes immensely towards the development of innovative mechanisms for strengthening the resilience of root and tuber crop.

\section{Keywords}

Agricultural intensification · Sustainability · Adaptability

\section{Introduction}

The root and tuber crops are group of plants which yields tubers, starchy roots, corms, stems, and rhizomes. Okigbo (1989) defined while tuber crops as crops with edible carbohydrate-rich storage organs developing wholly or partly from underground stems while root crops as edible crops with energy-rich underground plant structures developing from modified roots. Major tropical root and tuber crops are: cassava (Manihot esculenta); potato (Solanum spp.); sweet potato (Ipomea batata); yam (Dioscorea spp.); aroids like elephant foot yam [Amorphophallus paeoniifolius (Dennst.) Nicolson]; taro [Colocasia esculenta (L.) Schott.], and tannia [Xanthosoma sagittifolium (L.) Schott.]. Additionally, there are minor tubers such as Chinese potato [Plectranthus rotundifolius (Poir.) J.K. Morton.]; yam bean [(Pachyrhizus erosus (L.) Urban], and arrowroot [Maranta arundinacea (L.)]. These crops are vegetatively propagated and plays major roles in food sector 
especially by managing the well-being of people in developing countries. According to FAO (2009), these crops are produced in approximately 53.93 million hectares globally and this produce about 736.747 million tonnes annually.

In Sub-Saharan Africa (SSA), many people highly depend on root and tuber crops but not all as a contributory if not the primary source of their food and nutrition. This is also because of the role they play in food security, their ability to resist drought, as well as their capacity for commercial processing in Kenya. Actually they were ranked as the second most important food crop in 2019 by the ministry of agriculture after cereals (MoALF 2019). At the moment, the Kenya is producing 3.68 M MT of Irish potatoes, cassava, sweet potatoes, yam, and cocoyams. However, their yield is below average which is much way below country's potential. For instance Irish potatoes stands at 7MT per ha compared to the potential of 25 MT achieved under optimal husbandry practices (MoALF 2019).

Root and tuber crops are considered to be resilient because they are more adaptable to marginal areas. This areas are characterized by edaphic and climatic conditions that may not be favorable to the non-native materials. These crops are tolerant to poor soils and drought stress. They also grow very well on welldrained soils, with good organic matter, and especially those with loose and friable fertile clay loam or loam. Moreover, the optimal conditions for their growth are: annual rainfall ranging between 1000 and $2000 \mathrm{~mm}$, temperature of $18-35{ }^{\circ} \mathrm{C}$, and a soil $\mathrm{pH}$ ranging between 5 and 7.5. Nevertheless their planting differs from another case in point Coleus potato, tuberous rhizomes, or seed tubers are normally planted about $5 \mathrm{~cm}$ in depth on raised beds and are spaced at $15-20 \mathrm{~cm}$ while in Amora; they are planted at about $15 \mathrm{~cm}$ deep and a distance of 30-40 cm (Codd 1985).

These crops are also well known to serve as important components of subsistence farming system in their native areas and have played crucial, if not weighty roles income generation and in household food security of the rural areas. As food crops these crops are very rich in carbohydrates and on that account they play a paramount role as part of our daily diet, accounting for over $50 \%$ of the total staple food. In terms of energy requirements for global population, they contribute 3.9\% energy that is sweet potato $1.5 \%$, cassava $1.9 \%$, yams and other root and tuber crops $0.3 \%$. Along with this potatoes produce additional protein and dry matter per hectare than key cereals (Birch et al. 2012). Monneveux et al. (2013) also reported that potatoes have higher water generative capacity than cereals and are considered among the most energy productive crops, producing $5,600 \mathrm{kcal} / \mathrm{m}^{3}$ of water, compared to 3860 in maize, 2300 in wheat, and 2000 in rice. Other root and tuber crops such as taro, yautia, and yam, also have notable energy values and inconsistent nutritional properties, including vitamin $\mathrm{C}$, dietary fiber, and carotenoids (Asiedu and Sartie 2010). At the same time these crop plays a meaningful role as cash crops. They literally hold strong economic potential and can be financially rewarding to the agricultural economies. Finally these crops are progressively being used as a source of raw material for industrial use and for feeding the livestock. In comparison to other staple food crops, they provide comparatively 
huge amounts of nutrition and energy per unit area and time, they require lessintensive management systems even under risky environmental conditions. Consequently, these crops are very important in fighting famine caused by floods, droughts, civil strife, and other climatic catastrophe such as pests and diseases which seems to be unending in some countries.

Climate change is a menace posing extreme stress to the environment and also to the humans. Deschenes and Greenstone (2006) reported that it has an adverse effect on humans and their income-generating activities especially agriculture owing to its dependence on nature, largely temperature and precipitation. In addition climate change influences soil functions both directly and indirectly. The direct influence include soil process, namely, changes in organic matter and nutrient cycling and this is through adjusting temperature and moisture regimes or through increased soil erosion rates caused by increased frequency of intense rainfall occurrence. This causes severely effects on agriculture especially on the crops being grown. As a matter of fact, Africa is one of the riskiest continents to the ongoing climate variability causing robust negative economic impacts. This vulnerability is accentuated by development challenges specifically ecosystem degradation and endemic poverty which are supported by limited access to capital, infrastructure, markets, and technology (IPCC 2007).

Small-scale farmers in sub-Saharan Africa, who are the majority, have historically been confronted with high climate variability. Some of its negative effects on farm include decreased soil fertility and limited plant growth (Dhankher and Foyer 2018). Despite smallholder farming systems having proven to be resilient and being viable in risk-prone environments, climate change is likely to outpace their current coping capabilities (Morton 2007), if effective measures are not implemented. Specifically, low levels of income and technology, coupled with isolation from markets and lack of institutional support, are common characteristics of smallholder farming systems that make them particularly vulnerable to changes in external conditions (Morton 2007). This is worsened by the fact that food security and livelihood programs mostly stress on grain crops such as maize, rice, and wheat. In support of this, Atakos (2018) reported that only one or two studies have looked into the future potential of root tuber crops and their possible importance even with climate change. Our dependence on this relatively small number of food species therefore elevates serious concerns of feeding the whole world sustainably. In such context, investment in sustainable agricultural technologies and practices becomes crucial for adaption to sustain crop productivity to be able to feed the growing populations. In particular to able to reduce the negative effects of climate change on the agri-food system, Sombroek and Gommes (1997) proposed that populations and economic systems must be able adapt to future climatic conditions.

Since root and tuber crops play a great role as source of nutrition, and on the other hand, researchers are advocating for mitigation and adaptation as possible options to combat the adverse effects of climate change on agriculture, this chapter therefore focus on agricultural interventions that can enhance climate change adaptation of underutilized root and tuber crops. 


\section{Major Roots and Tuber Crops}

\section{Cassava}

Cassava (Manihot esculenta) is a perennial woody shrub which grows as an annual crop. It is also referred as manioc, mandioca, or yuca, which is in the spurge family (Euphorbiaceae) (Hillocks et al. 2002). This crop is also known as the "king of tropical tuber crops" and has a significant position in the global agricultural economies. According Bennett (2015), the crop is ranked as the second most important food source in Africa with regard to calories consumed per capita. Cassava is native to South America (Allem 2002) but it is grown all over tropics and subtropics. It is largely produced in Brazil followed by Thailand, Nigeria, DR Congo, and Indonesia, even though about half of the global production is in Africa. The crop is grown in about forty African countries where it is recognized as an important food crop particularly in Nigeria, DR Congo, Ghana, Mozambique, Uganda, Cameroon, Madagascar, Angola, Côte d'Ivoire, Tanzania, Benin, and Kenya. FAO 2000 revealed that about $70 \%$ of Africa's cassava production is obtained in Nigeria, Tanzania, and DR. Congo.

It has been proposed that cassava could potentially be hardy to climate change than other staple crops (Jarvis et al. 2012). Likewise Nweke et al. (2002) revealed that cassava can grow well in marginal lands, and that it requires low farm inputs. The average cassava root yield is about $11.6 \mathrm{t} / \mathrm{h}$ worldwide (FAO 2018) which is exceedingly lower than its potential yield of $60 \mathrm{t} / \mathrm{ha}$ under better farming practices which was reported in some parts of Africa (Kintché et al. 2017). Even though FAOSTAT (2014) reported that world production of cassava storage roots improved tremendously from 176 to 277 million Mg between 2000 and 2013. Major limiting factors for cassava production are low soil fertility and pests and diseases.

\section{Sweet Potatoes}

Sweet potato (Ipomoea batatas (L.) Lam) is a herbaceous dicotyledonous plant belonging to Convolvulaceae family (Purseglove 1972). The plant has creeping, perennial vines and adventitious roots (Purseglove 1972). It is grown for its green leaves and storage roots which are very useful for human consumption, feeding animal, and to a certain extent, for industrial purpose (Woolfe 1992). For that reasons, according to Motsa et al. (2015), the crop plays a critical role for food security and income generation for many households. Consequently, the crop is extensively cultivated in tropical, subtropical, and frost-free temperate climatic areas of the world (Onwueme and Sinha 1991).

Sweet potato is ranked as the seventh most important food crop globally because it contributes majorly in terms of energy and nutrition (Marques 2015). The crop also matures at a very short time on marginal lands and play an important role in the economy of poor households (Nath et al. 2007). As stated by Ukom et al. (2009), the crop is important for its storage roots which can either be baked, cooked, fried, or 
roasted for human consumption. Its storage roots can also be processed into flour for baking bread, making noodles, as well as for alcohol production. In addition, the storage roots are very good source of vitamin A, vitamin C, vitamin B6, dietary fiber, manganese, copper, potassium, and iron (Baybutt et al. 2000). Even though the crop has a high storage root yield potential ranging between 20 and $50 \mathrm{t} / \mathrm{ha}$ (Kivuva et al. 2014), in Sub-Saharan Africa, this is yet to be realized since its production is still less than 10 t/ha (FAOSTAT 2017).

\section{Yam}

Yams (Dioscorea spp.) are tropical plants with large food reserve in their underground tubers and comprise of various species that originated from Southeast Asia, West Africa, East Africa, Brazil, and Guyana. The main species are Dioscorea alata (greater or water yam), Dioscorea cayenensis (yellow guinea yam), Dioscorea esculenta (lesser yam), and Dioscorea rotundata (white guinea yam) (Arnau et al. 2010), and this comprises both annual and perennial species. They cultivated all over the tropics and in some parts of subtropics and temperate areas. FAO (2000) reported that up to $95 \%$ of the world's production is realized in West Africa.

The tubers are very important and constitute stored wealth since they can be sold all-year-round by farmers because they can be stored for relatively longer period of time in comparison with other tropical fresh produce (Aidoo 2009). The tubers also provide a substantial amount of vitamins (vitamin B1 and C), potassium, and iron (Rudrappa 2013). Most essentially many of the yam species have high content of steroidal saponins which make them suitable for industrial use as corticosteroids precursors and anti-cancer bioactive compounds. Besides being staple food that is consumed by about 155 million people in the world, yams are grown as cash crop, as medicinal plant, and have high cultural value for the groups cultivating it (Coursey 1981).

Major hindrance for intensifying yam productivity is low soil fertility (both in terms of macro- and micronutrient deficiency) (O'Sullivan and Ernest 2007). This is because Dioscorea spp. are high-nutrient-demanding crops (Carsky et al. 2010). Therefore, yams still remains being categorized as orphan crop (Naylor et al. 2004).

\section{Irish Potato}

Irish potato (Solanum tuberesum L.) is indigenous to South America near the present border of Peru and Bolivia but not Ireland (Spooner et al. 2005). According to Robert and Cartwhight (2006), it belongs to the family solanaceae, and is named after Ireland country because it is associated with the Irish potato famine, also known as the Great Hunger. This was a historic famine caused by Phytophthora infestans which infected Irish potato crop. This crop plays a crucial role in the economy and is ranked number one non-grain food commodity (Rykaczewska 2013). Globally it is ranked third most important food crop in consumption after rice and 
wheat (Birch et al. 2012). It has a worldwide cultivation exceeding 19.34 million hectare in more than 158 countries, with an approximate yearly production of 364 million tons (FAOSTAT 2014). According to Tshisola (2014) in Africa, it is regarded as one of the most important food crops.

Practically the crop contains all the requisite dietary components such as protein, vitamins, carbohydrates, essential nutrients, and minerals (Sriom et al. 2017). Additionally it is a source income and employment opportunity in developing countries. Unfortunately, limiting factors to its production include short day lengths, low light intensities, high temperatures, and most importantly low soil fertility (Jones and Wendt 1994).

\section{Cocoyams (Arrow Roots)}

Cocoyam (Colocasia esculenta (L.) Schott.) is a member of Araceae family (Purseglove 1975) and is a subsistence and emergency food source globally (IFA 1992). It is an important starchy tuberous herbaceous perennial plant (Purseglove 1975). The crop has different varieties and commonly produced varieties are Colocasia esculenta (Taro) and Xanthosoma sagittifolium (Tannia). They also occur in all tropics and have been domesticated in most communities in Oceania, Africa, and Asia (Ramanatha et al. 2010).

The crop is cultivated for its edible cormels, corms, and leaves as well as other traditional uses (Pinto and Onwueme 2000). As food for consumption, it is essentially a source of calories obtained from underground corm and cormel (Davies et al. 2008). Their leaves which resemble spinach are nutritious and are source mineral and vitamin (Sefa-Dedeh and Kofi-Agyir 2002). Primarily, fresh cocoyam hold about $70-80 \%$ water, $20-75 \%$ carbohydrate, and $1.5-3.0 \%$ protein (Udo et al. 2005). It actually contains over $80 \%$ and $240 \%$ higher digestible crude protein than yam and cassava, respectively. Therefore this crop is high-ranking nutritionally than cassava and yam in terms of protein and other elements such as vitamin and mineral content. However, the crop still remains to be underexploited food resource (Onyeka 2014).

\section{Root and Tuber Crop Production in Kenya}

Ministry of agriculture, livestock, and fisheries of Kenya report indicate that roots and tuber crops production stagnated for a period of 3 years (2012 to 2015) with an average cultivated zone of about 240,000 ha, which gave a total production level of 3.3 million MT although these reduced to 2.4 MT in 2016 (MoALF 2019). This elicited the national government to draft a strategy (the national root and tuber crops development strategy 2019-2022) to help in upscaling their production. This was an initiative of the national government of Kenya, but it was being supported by other key stakeholders such as the European Union, and by organizations like Self Help Africa (Table 1). 


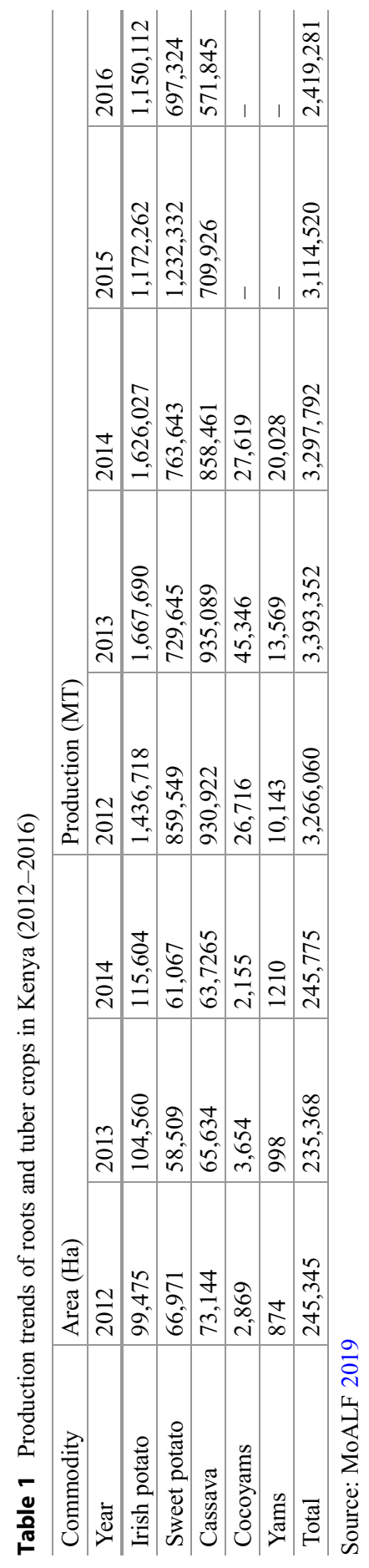


Fig. 1 Forecast sustained per capita demand for roots and tubers to 2050. (Source:

Wiebe 2015). WLD = World;

$\mathrm{EAP}=$ East Asia and Pacific;

$\mathrm{EUR}=$ Europe;

FSU $=$ Former Soviet Union;

LAC $=$ Latin America and

Caribbean; $\mathrm{MEN}=$ Middle

East and North Africa;

$\mathrm{NAM}=$ North America;

SAS = South Asia;

SSA $=$ sub-Saharan Africa

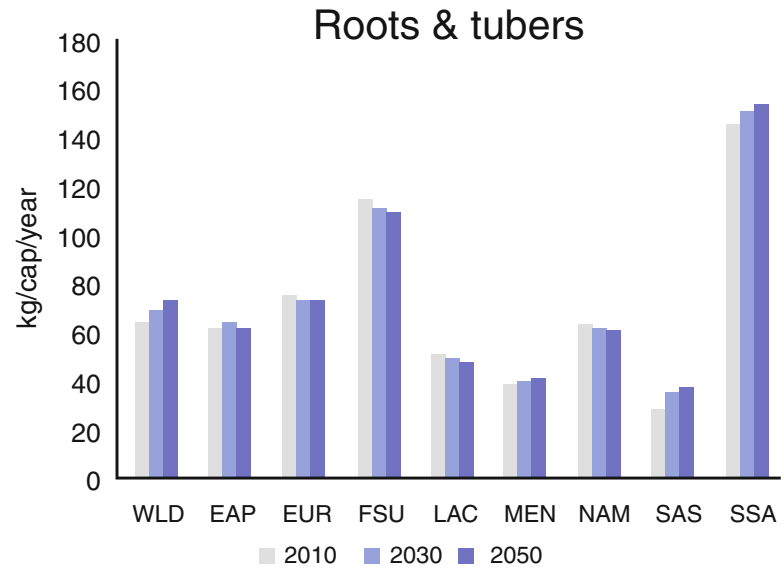

In sub-Saharan African counties, there are noticeable cultural preferences for root and tuber crops, and using the Impact General Equilibrium Model, a 2015 analysis the International Food Policy Research Institute revealed that per capita consumption of these crops continues to rise (Fig. 1). Therefore, because of its low productivity brought by the effects of climate change and which cannot meet their demand, there is need to enhance their resilience to climate change using innovative ways.

\section{Agricultural Interventions for Adaptation to Climate Change}

Farmers, especially small-scale farmers, still use indigenous farming practices which lead up to ultimately low yields. This is coupled to farmer's nonadoption of better crop production strategies and lack of improved and high-yielding varieties. Moreover, these farmers on their own do have other alternatives that can help them bear and share loses or modifies threats. On the other hand, climate change adaptation should be built on sound and a working ecosystems, as it provides a variety of benefits and services on which agricultural production systems and rural livelihoods depend. Therefore, this calls for adoption of new technologies while producing these crop to help us throughout this challenging times. To this end, this chapter provide the suitable technologies available that can be exploited to increase root tuber crops adaptability to climate change. The technologies include:

\section{Bio Fertilizers}

By definition, bio fertilizers are products containing natural occurring microorganisms that are artificially multiplied for ameliorating soil fertility. Each and every type of crops grown in different agro-ecological zones can benefit from their 
use, since they are valuable to the environment. This is because they are enabling farmers to minimize the use of modern chemical fertilizers in crop production. In particular, they are designed to improve nutrient availability or reduce pest pressure. According to Malik et al. (2011), constant use of microbial-based bio-fertilizers enables microbial population to persist in the soil which helps in soil fertility conservation (Table 2).

Phosphate-Solubilizing Microorganisms (PSM): They are a group of beneficial microorganisms that capable of hydrolyzing inorganic and organic insoluble phosphorus compounds to soluble phosphorus form that can easily be absorbed by plants. They include various soil fungi and bacteria, and important species are Pseudomonas, Bacillus, Penicillium, and Aspergillus. Hikmatullah and K. Nugroho (1994) reported that their abilities of phosphate solubilization from organic materials differs due to their differences in their capacity to produce organic acids that play a key role in releasing phosphorus bound by aluminum, iron, and calcium ions. Specifically, this is because organic acids released by microorganisms are different in quantity and quality (Jha et al. 2013). Some of the organic acids released that are capable of freeing AI-P bond include Malic acid, malonic, tartaric, oxalic, and citric (Marbun et al. 2015). These organic acids decrease the soil pH in their locality to cause the dissolution of bound phosphates in soil. Khan et al. (2009) reported that $1 \mathrm{~g}$ of fertile soil can hold $10^{1}$ to $10^{10}$ bacteria, and their live weight may exceed 2,000 $\mathrm{kg} \mathrm{ha}^{-1}$. Similarly Chen et al. (2006) outlined that among the whole microbial community in soil, phosphate solubilizing bacteria comprise $1-50 \%$ while phosphate solubilizing fungi comprise $0.1-0.5 \%$ of the total respective community. Therefore, microbial-based biofertilizers can be utilized to boost soil microbial population whenever they are low and when cultivating root and tuber crops. With high density of PSMs, it is expected that microbial phosphate solubilization can compete effectively with other microorganisms in the soil.

Phosphorus Mobilizing Fungi: This group comprise of the arbuscular mycorrhiza fungi (AM fungi) that belongs to the phylum Glomeromycota (Schüßler et al. 2001). The fungi form a mutualistic relationship with most terrestrial plants. In the association, the plants benefit through various ways such as water and essential

Table 2 Types of biofertilizers for root and tuber crops

\begin{tabular}{l|l|l}
\hline \multicolumn{2}{l}{ Phosphorus-solubilizing microoganisms } \\
\hline 1$)$ & Bacteria & $\begin{array}{l}\text { Bacillus megaterium var. phosphaticum, Bacillus subtilis, Bacillus } \\
\text { circulans, Pseudomonas striata }\end{array}$ \\
\hline 2$)$ & Fungi & Penicillium sp, Aspergillus awamori \\
\hline
\end{tabular}

\section{Phosphorus mobilizing fungi}

\begin{tabular}{l|l|l} 
1) Arbuscular & Glomus sp., Gigaspora sp., Acaulospora sp., Scutellospora sp. \&
\end{tabular} mycorrhiza fungi Sclerocystis sp.

\section{Micro nutrients solubilizers}

1) Silicate solubilizers $\quad$ Bacillus sp.

Plant growth promoting rhizobacteria

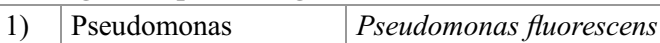

Source: (Kumar et al. 2017) 
nutrients uptake, and also by enhancing plant tolerance to biotic and abiotic stresses (Augé et al. 2015). This multifunctional ability and diversity of AM fungi has led to the development of mycorrhizal inoculants for use as biofertilizers in agriculture. Actually, most land plants are facultative symbionts such that they gain from AM fungi, yet they can also live without them, although at reasonable fitness cost. However, some plant species are obligate parasites on the fungus such that they are fully dependent on fungal nutrition (mycoheterotrophs) and have lost photosynthetic capacity (Graham et al. 2017).

Since mycorrhizal inoculations has been used for decades to stimulate plant growth for several crop, root and tuber crops which are highly mycorrhizal could also profit from the numerous services offered by this fungi not only in increasing their resilience to climate change but also their productivity. For instance, according to a report by Sieverding (1991) AM fungi inoculation of cassava increased its fresh roots weight by up to $5 \mathrm{t} / \mathrm{ha}$.

Micronutrients Solubilizers: Such as Silicate solubilizing bacteria (SSB) are microorganisms that are able to degrade silicates and aluminum silicates in soil. These microorganisms such as Collimonas, Janthinobacterium, Proteobacteria, Aminobacter, Burkholderia, Dyella, and Frateuria are reported to solubilize the biotite which hold substantial amounts of silicate minerals (Uroz et al. 2009). During their metabolism, various organic acids are released which plays double roles in silicate weathering. These species supply hydrogen ions to the media which encourages hydrolysis. As well the organic acids let out such as oxalic acid, Keto acids, citric and hydroxyl carbolic acids form complexes with cations, which foster their removal and retention in the media in a dissolved state.

Since phosphorus and potassium are crucial macro elements for plant growth and development, $\mathrm{P}$ and $\mathrm{K}$ chemical fertilizers are regularly applied to replace the removed minerals in soil for yield optimization; SSB also plays an efficient role not only in solubilizing insoluble forms of silicates but also potassium and phosphates, hence this microorganisms when applied would increase the soil fertility, thereby enhancing root and tuber crops productivity.

Plant Growth Promoting Rhizobacteria (PGPR): Also referred as yield improving bacteria (YIB) are a group of bacteria that are known to increases plant growth and yield by-way-of several plant growth promoting substances as well as bio fertilizers. They are distinguished as free-living soil microorganisms colonizing plant roots and brings into play a beneficial effect on plant development and/or subdue plant pathogens. The microorganisms include; Alcaligenes, Agrobacterium, Bacillus, Bradyrhizobium, Burkholderia, Enterobacter, Frankia, Klebsiella, Pseudomonas, Arthrobacter, Azospirillum, Azotobacter, Rhizobium, and Serratia. The genera enclose most PGPR with well-known benefits on different crop species (Tailor and Joshi 2014).

There are numerous mechanisms through which the bacteria helps the plants including: inducement of increased nutrient uptake (termed Bio fertilizers), provision of nutrients by way of nitrogen fixation and phosphate solubilization, better plant growth promotion through the production of phytohormones (termed Bio stimulants), and the suppression of plant pathogens or the induction of systemic 
resistance to diseases (termed Bio protectants) (Vessey 2003). Also species of Pseudomonas and Bacillus produce plant growth regulators that stimulate crops to produce many fine roots which increases the surface area over which plant roots absorb water and nutrients.

Due to their multiple roles, research on these growth regulators has been rising and a number of experiments (both in vivo and in vitro) have been tested on different crops including root and tuber crops. For example, Bacillus and Pseudomonas sp. have been tried on potatoes and they have helped in improving phosphorus uptake, promoting indole acetic acid (IAA) production, and for biocontrol (Hunziker et al. 2015). Therefore, these microorganism can be very useful in fostering the growth and yield of root and tuber crops, with minor inputs of agrochemicals.

\section{Organic Agriculture}

Organic agriculture can be defined as a production system that sustains the health of soils, ecosystems, and people. This management system helps in mitigating climate change by diminishing the emissions of greenhouse gases and by sequestering carbon dioxide from the atmosphere. Organic agriculture is reported to be the most sustainable approach in food production. This is because it highly emphasizes on recycling practices and use of low external input for realization of high output. In addition, its principles dwell on increasing soil fertility, its diversity at all levels, and mitigating soil erosion.

Some management options of organic agriculture are generally considered to have both mitigation and adaptation benefits since they increase soil carbon. Ciais et al. (2013) stated that soil carbon provides a mitigation benefit by storing carbon taken out of the atmosphere by plants during photosynthesis. Soils with higher amounts of carbon are associated with greater water holding capacity, increased nutrient availability, and higher yield potentials, which could prove adaptive in a future climate (Stokes and Howden 2010). Organic agriculture practices are innovative way that can be used to increase these crops adaptability to climate change.

\section{Soil Organic Matter Management}

Soil organic matter (SOM) is a major measure of agricultural productivity and general soil health. Mean annual temperature and precipitation are major climatic drivers of SOM levels and dynamics. Long-term field trials and farm comparison show that organically managed soils have notably higher organic matter content. According to Foereid and Høgh-Jensen (2004), it was evaluated that under Northern European conditions, changing from conventional to organic agriculture resulted in enhanced SOM ranging from 100 to $400 \mathrm{kgha}^{-1}$ yearly during the first 50 years. Therefore, after a hundred years of organic agriculture, it is estimated that a steady state of stable level of SOM would be realized.

Environmental Protection Agency estimated that composting 1 ton of organic matter gave a net storage of about 600 pounds of carbon dioxide (EPA 2006). Even though all kinds of agriculture poses the capability of sequestering carbon, essentially organic agriculture can sequestrate remarkably more carbon than conventional 
systems (Don 2007). This is because organic agriculture restrains the use of chemical fertilizer and pesticide and integrates use of cover crops especially from leguminous plants, and place in order increasing soil organic matter as the first step. Therefore, to sequester more carbon as possibly brought up by climate change, it is necessary to incorporate SOM management practices when producing root and tuber crops.

\section{Mulching}

Mulching is a traditional practice which involves the covering of soil surface with organic material which plays a vital role in soil and plant protection. Mulches are capable of changing the environment around the plants and control weed sand annual grasses, soil erosion and runoff, and soil-borne diseases. Besides, they decrease moisture evaporation, increase water absorption and retention, and boost root growth. Organic or natural mulches such as compost provide many favorable and fertilizer-like effects for root and tuber crops production by supplying abundant plant nutrients, during their decaying process.

Owing to climate change that has resulted in land slide, high temperature and flashfloods, mulching is necessary since several types of mulching practices have exhibited reduction in soil erosion by more than $90 \%$ compared to bare soil (Mostaghimi et al. 1994). Unger (1994) argued that mulches with low carbon to nitrogen ratio decompose rapidly providing nutrients for crop growth at a faster rate. Furthermore, studies in Latin America and Papua New Guinea revealed the benefits of mulching cassava and sweet potato plants for yield stabilization (Ossom et al. 2001). To support this, Coling (1997) reported that mulches of plastic film enhanced dry matter accumulation, plant height, leaf area index, and tuber yield of potatoes. Similarly Sarma et al. (1999) after planting potato cv. Kufrimegha on ridges and flat seedbeds in combination with mulches and earthing up, he confirmed that mulching with black plastic film resulted in enhanced tuber yield which was greater than the normal cultivating method. This is because plastic mulch literally conserved the soil moisture which helped in better crop growth and tuber yield. Similarly, mulching the soil has been positively correlated with plant species richness.

As a normal practice, root and tuber crops are usually cultivated on ridges where soil erosion and weeds can be a menace. Therefore, for their effective production mulching is important since it is a valuable practice that can be used to control weeds. This is because mulching prevents weed growth and development by blocking light from reaching the soil surface where their seeds lie. In root and tuber crops, mulching could assume an important function of lowering soil temperatures in addition to soil moisture conservation (Sangakkara et al. 2004).

\section{Zero Tillage}

Zero tillage which is also referred as direct drill or no till is an agricultural practice of cultivating crops or pasture without disturbing the soil surface through tillage. Its aim is to conserve soil and moisture through nondisturbance of the soil surface and also by ensuring that $30 \%$ or more of crop residues are conserved on the surface (Erenstein and Laxmi 2008). According to Fernández et al. (2010), the practice has been documented widely for its benefits including protecting the soil against erosion 
Table 3 Area under zero tillage by continent

\begin{tabular}{l|l|l}
\hline Continent & Area (ha) & Percentage of total (\%) \\
\hline South America & $49,579,000$ & 46.8 \\
\hline North America & $40,074,000$ & 37.8 \\
\hline Australia and New Zealand & $17,162,000$ & 11.5 \\
\hline Asia & $2,530,000$ & 2.3 \\
\hline Europe & $1,150,000$ & 1.1 \\
\hline Africa & 368,000 & 0.3 \\
\hline World total & $115,863,000$ & 100 \\
\hline
\end{tabular}

Source: Derpsch et al. (2010)

and managing soil structure. Also, this practice increases carbon sequestration and activities of the microorganisms (Helgason et al. 2010) (Table 3).

Studies show that practices that reduce soil disturbance and intensify cropping have the potential of increasing soil organic matter (SOM) and improving soil health. For instance, soil disturbance with tillage generally promotes loss of SOM by facilitating microbial degradation of SOM, promoting crop-residue-soil contact, and placing residues into more favorable subsurface moisture regimes as compared to surface placement under no-tillage (Halvorson et al. 2002). By adopting no till practices in root and tuber crops production, soil conservation would be improved greatly, water and wind erosion would be considerably reduced, while the crops would yield more since they would protect from pests and external environment.

\section{Tie-Ridging}

Tie-ridges are soil and moisture conservation structures that involves the construction of small basins that are rectangular shaped. This basins are formed within the furrow of cultivated fields mainly to enhance the storage of rain water and for allowing more time for water to percolate in the soil (Wiyo et al. 1999). Belachew and Abera (2010) reported that the stored water can accessed by plants for a longer period of time better than it can be used when there is run off. Ridging across slope is highly recommended in dry areas for soil and water conservation in crop production (Kumwenda 1999).

Mechanized ridging is achieved either by animal-drawn ridgers, as it is commonly practiced in African for cassava and other food crops production, or by tractor-mounted ridgers which is a major practice for cassava production in Asian countries (Suyamto and Howeler 2001). The purpose of mechanization is to reduce hard work and in the process increase the scale of production crops. Although when using tie-ridging the optimum height of the ridge depends on the soil type and the cultivar being grown.

Benefits of tie-riding reported include: increased number of roots per plant which is identified as a major contributory factor to the higher yields on ridges (Suyamto and Howeler 2001). In particular, ridging has been shown to increase sweet potato yields by $38 \%$ (Ennin et al. 2003) over mounding, mainly as a result of increased 
plant population density and better weed suppression on ridges. Shetto (1999) reported that many farmers find weeding of cassava to be easier on ridges than on mounds; it is also effective in soil erosion management and results in high yields. Ennin et al. (2009) recommended the cultivation of cassava, yams, and other tuber crops on tie-ridges for realization of economizing the available planting space and thus increase on the planting density. Ridging is also responsive to improved farming practices such as herbicide application, fertilization, and yam staking, and this is due to the regular spacing of crops obtained under the systems.

The concept behind creation of tie-ridges is to optimize water infiltration, improvement of soil-water management, enhancement of root growth and nutrient uptake, and enhancement of rooting depth which is also supported by FAO (2000). Therefore, tie-ridge would play a significant role in production of root and tuber crops.

\section{Improved Seed Varieties}

Unlike the other true seed crops, root and tuber crops are propagated vegetatively. The benefits of improved seed varieties for root and tuber crops can only be realized through breeding and addressing the challenges in their seed value chain. This can be achieved through having a functioning seed systems and directly linking of the systems as a key tool of addressing the issue of improved seeds. This can further be linked in addressing the issues of climate change.

To this effect, the International potato center (CIP) has fostered and expedited their breeding schemes that shortens the time it takes in developing and releasing new varieties of root and tuber crops actually from 8 to 4 years. To this effect, their breeders have released potato varieties that are tolerant to heat, salinity, and drought. Some of the varieties are Tacna and Unica which were developed and tested in Peru; Raniag variety in Philippines; and Kinga, Kiningi, and Meva developed in Africa (Atakos et al. 2018). Further variety Tacna was released in the Republic of China under the name Jizhangshu 8 , and had covered 20,000 ha by 2008 . Recently work has been going on to develop climate change resilient potatoes that have the characteristics of drought and salinity tolerance, and according to Atakos et al. (2018), variety Sarnav has been released in Central Asia (Uzbekistan and Tajikistan), while heat and salinity tolerant BARI Alu-72 has been released in Bangladesh. With minimal precipitation being realized ranging between $15 \%$ and $20 \%$ and new experiences in temperature increase of $2-3{ }^{\circ} \mathrm{C}$ due to the effects of climate change, these clones have shown a high degree of tolerance to these effects (CIP 2017). On that account, such efficient breeding practices that delivers improved seed varieties of root and tuber crops should be supported especially in the area of improving their resilient to climate change.

\section{Management of Community Seed Banks}

Community seed banks are entities that are governed locally and they are managed in an informal manner by institutions whose core function is to maintain seeds for 
local use (Development Fund 2011). Vernooy et al. (2014) reported that the community seed banks were founded by Rural Advancement Foundation International (RAFI) now known as ETC Group or Action Group on Erosion, Technology, and Concentration. The three key functions of the community seed banks are: (i) to conserve the plant genetic resources; (ii) to make the availability and accessibility of diverse seeds and planting materials according to farmers' needs and interests easier; and (iii) facilitating seed and food sovereignty (Vernooy et al. 2014). Community seed banks are globally located in Guatemala, India, Malaysia, Mexico, Nicaragua, Sri Lanka, USA, Honduras, Bhutan, Bolivia, Brazil, Canada, Bangladesh, China, Costa Rica, Nepal, Trinidad and Tobago, Rwanda, Uganda, Mali, Burundi, Norway, Zimbabwe, and South Africa. Recently it was launched in Kenya in Nyando in smallholder farmer areas by the Consortium of International Agricultural Research Centers (CGIAR) research program on climate change agriculture and food security (CCAFS) in sub-Saharan Africa which works in partnership with Bioversity International to establish community seed banks in Kenya, Tanzania, and Uganda. The idea behind is that when you take one seed you return two, if you take five, you return ten. This protocol aids in their sustainability. The idea of community is excellent; however, the existing community seed banks are focused on cereal crops neglecting the root tuber crops. Although the International Potato Center (CIP) researchers are promoting innovative ways that allows storage of seeds of root and tuber crops.

Specifically sweet potatoes farmers are encouraged to mass-produce their own vines during planting time. The system is known as Triple $\mathrm{S}$ (for storing vines in sand to make them sprout). It involves storing the vines in dry sand following harvest, and thereafter planting them in seedbeds $6-8$ weeks before the rainy season, and watering them to produce enough vines to plant when the rains begin. The practice results in increased vines, earlier harvests, which provides food and income at a time. In addition in order to maintain disease free planting materials, the farmers in high virus pressure zones are advised to use net tunnels systems to protect against insects such as whiteflies and aphids which are known in spreading viruses. This practice is effective in suppressing the infection rate by sweet potato virus disease thus supporting the availability of clean planting materials. According to Atakos et al. (2018), such tunnels also have contributed in moisture retention by reducing the amount of water required for irrigation. The major benefits derived from community seed banks that can be exploited for production of root and tuber crop seeds are pest and disease reduction, increased production of seeds, and climate stress buffering.

\section{Cropping Systems}

Cropping systems plays important roles in crops adaptability to climate change since the practice encompasses on farm adaptation of improved farming technologies and in this case planting more than two crops with different maturity periods. This system has various advantages including: better utilization of the environment, 
greater food yield, increased return per unit area, and insurance against crop failure. Therefore, root and tuber crops which have great flexibility can be part of such a system. This is because they can be intercropped with plantation crop such as areca nut, coconuts, coffee, rubber, and fruit crops like mangos, bananas, and litchi as these crops are adapted to the same ecological conditions (Nayar and Suja 2004). In this system, the principal crop provides cash while root intercrops provide as highenergy secondary staple to the farm family and feeds for farm animals, behave as insurance crop against risk and natural calamities, ensure food security, enhance resource use efficiency, augment net income, and increase employment opportunities.

To support this, cultivation of root and tuber such as yam, cassava, sweet potatoes, and edible aroids in the interspaces of perennial plantations such as rubber, coffee, coconut, and banana is common in tropical countries. Crops such as elephant foot yam and yam grow as intercrops horticultural and planation crops. Also intercropping maize and yam is believed to be productive and compatible mainly because maize is a short season crop (3-4 months), while yams are long are long duration (7-12 months) crops. Sagoe (2006) also revealed that yams and cocoyams are usually cultivated in association with cocoa and furthermore new innovations propose use of cassava trees in cocoa production. Davis et al. (1986) reported that sweet potato are grown as intercrop and in rotation systems with crops like soybean, bean, sorghum, maize, and cassava. In India, cassava, yams, and edible aroids are intercropped with rubber plantations during their immature phase whereas in Malaysia cassava is grown as intercrop in Rubber estates (Leihner 1983). The cropping system also includes practices such as adjusting the planting dates, irrigation applications, and fertilizer application (Sagoe 2006). This examples suggests that when managed appropriately, cropping systems can enhance the adaptability of these crops to climate change especially when the right crops are chosen for the system.

\section{Irrigation Method}

Climate change causes in drought which is a major abiotic factor that limit crop production. On the other hand, global warming causes rainfall fluctuations increasing the risk of plant exposure to repeated drought (Miyashita et al. 2005). Other factors ever berating the drought situation include limited fresh water bodies which cause serious issues globally, particularly in arid and semiarid regions. These fresh water bodies are also decreasing due to population pressure, comping demands from the industries, low rainfall, agricultural and urban development. Furthermore drought is considered one of the major constraints for root and tuber crop production.

Root and tuber crops have much capacity in terms of their water use efficiency and nutrient use just like other food crops. Additionally, these crops have a unique growth characteristics and functionality. Therefore a suitable irrigation method must be selected while cultivating these crops such as: an irrigation method that releases the exact amount of water required, and time and method of water application. To this end, sprinkle and trickle irrigation methods therefore becomes the best option for 
these crops. This is because they save irrigation water by up $30 \%$ and $50 \%$, respectively, as compared with surface irrigation (Al-Jamal et al. 2001). Amer (2011) revealed that in small-scale farming using gated pipes and double planting row beds, with partially wetted furrow irrigation, water saving is achieved just as in trickle irrigation. Even though partially wetted irrigation can be very useful especially because it decreases installation cost compared to trickle and sprinkle systems, in this case it is important to consider the right method for climate change adaptation. Considering this, trickle irrigation becomes the best method for theses crops under the prevailing climatic conditions since it conserves water, prevents nitrogen leaching, allows deep water percolation, and reduces soil erosion. Also it gives famers an opportunity to apply water at the right time.

\section{Exploiting Abandoned Lands}

In this chapter, land abandonment concept is used on a land where traditional or recently agricultural activities have stopped due to their marginal characteristics. Lands are classified as abandoned when their productivity level is situated close to the margin beyond which management expenses are not compensated by the profits obtained after harvesting. To this effect, cropland abandonment has become a common occurrence globally due to the improper agricultural practices being used.

To reclaim this types of lands and to increase the arable lands, alternative crop productions (in intensive form) should be used. This is because the remaining arable land is being lost to urban and industrial uses, deforestation, rural development, such as afforestation, and land fragmentation into smaller units. According to FAO (2011), many efforts to revamp land productivity have continued over the years since the abandoned lands represents a valuable resource for crop production. Such efforts are supported by the farmers desire to pass productive farmlands onto the future generation in just a good condition as when they inherited them (Greenland et al. 1998).

Root and tuber crops can therefore be very useful for use in reclaiming these abandoned lands. This is because of their agronomic advantage such that these crops are adapted to diverse soil, environmental conditions, and a variety of farming methods with minimum agricultural input. Also, variations in the growth pattern and adopting cultural practices make them specific in production systems. In addition, these crops are relatively easy to grow since they are highly adaptable in growing at a wide range of altitudes, on both flat and sloping lands, and on both sandy and clay soils where other crops are not well adapted. Finally, the variety to choose from for these crops is very high.

All these characteristics indicates that root and tuber crops have a comparative advantage for cultivation in marginal lands than other crops since they can be selected to resist stress conditions and in contributing to sustainable crop production with low input cost. Similarly, IPGRI (2000) reported that these crops contributes to the food crops diversity and hence exploits fully the abilities of agro-ecosystems. Under this scenario of large abandoned land, root and tuber crop can be produced effectively on these lands, and after years of their production, the lands can be 
returned for production of other agricultural crops production. In return this would lead to reduced clearing of additional forests and grassland for farming purposes.

\section{Agroforestry Practice}

Agroforestry is an interaction of agriculture and trees, including the agricultural use of trees. This encompass trees on farms and in agricultural landscapes; farming in forests and along forest margins and tree-crop production including coffee and cocoa. It ranges from traditional swidden agriculture to elaborate systems of fruits trees and vines in spatial complementarity. Examples of useful agroforestry trees include; Acacia albida, Leucaena leucocephala, Prosopis juliflora, Acacia scorpioides, and Euphorbia spp. Others include green manure crops such as Tephrosia $s p p$, Desmodium spp, Dolichos spp, and Indogofera spp.

Some of the most promising agroforestry techniques for root and tuber crops include: (a) Scattered farm trees, this simply involves the increase in number of trees in the middle of crops and alongside the farm boundaries. The trees might have greater value than the crops they displace. Alternatively, the trees might actually increase the productivity of these crops by replenishing the soil and helping reduction of soil erosion. (b) Improved fallows, which involves fallows being enriched with fast-growing trees, vines, or shrubs. This is required by the fact that the fallow periods in many areas needs to be shortened considerably. (c) Buffer strips, which are areas of land maintained in permanent vegetation that helps control soil, air, and water quality. Root and tuber crops can therefore serve as buffers against soil erosion when planted along contour lines of slopes. In complicated systems, these root and tuber crops buffer strips can include other crop, such as grasses, trees, shrubs, and fodder legumes.

\section{Clean Seed Production Technologies}

Policy makers acknowledges that seed security is pivotal for global food security. This is because seeds serves as the primary farm input in crop production and is also a means for conveying agricultural innovations to the farmers. Forasmuch as seeds are among the main factors that impediment crop production, these seeds must therefore be in good quality by the time they are distributed to the farmers. Actually availability, accessibility, and use of quality seeds that are adapted are of essence in increasing agricultural productivity and improving farmers livelihoods.

For clean seed production of root and tuber crops, cases reviewed encouraged seed stakeholders to emerge as permanent seed producers (Bentley et al. 2018). This would enable clean seed to flow through the value chain constantly. Methods of clean seed production include:

(a) Commercial farms being contracted for one season, even though the method has demonstrated that it is labor intensive, it is susceptible to pests and diseases, and it is time consuming. 
(b) Tissue culture, which is the growth of tissues of plants or animal in an artificial medium separate from the parent organism. This method is very important for plant propagation for example the use of this method in seed production has ensued in mass production of clean potato seeds within a short period of time. In support of this, Pruski (2001) revealed that the method is characterized by its flexibility in terms of the rapid multiplication of seedlings. This method has been adopted in several countries like Vietnam where it revolutionized production of potato seeds. The method is now well understood and has been used in propagation of several plant species across the globe.

(c) Aeroponic method: which is the process of cultivating plants in an air or mist environment without the use of soil or media. It is considered as one of the safest and ecological friendly method for producing natural and healthy crops. The multiplication of potatoes using this method of more advantage than other available systems. CIP (2018) reported that the method is ten times more successful than convectional techniques, hydroponics, and tissue cultures which takes much time and are more labor intensive. The method utilizes nutrient solution recirculation, thus water is not wasted and the available nutrients are used effectively. Therefore this system comparatively offers lower energy and water inputs per growing area. This system can therefore be utilized for rapid production of root and tuber crops seeds.

\section{Nutrient Use Efficiency (NUE)}

Nutrient use efficiency indicates the ability of crops to take up and utilize nutrients for yield. The concept entails three major processes in plants: uptake, assimilation, and utilization of nutrients. The nutrient uptake and fertilizer recommendation of important root and tuber crops are presented in Table 4. This is an indicator that root and tuber crops have a higher NUE. This is support by Nieto, C. O. (2016) who

Table 4 Nutrient uptake and fertilizer recommendation of important root and tuber crops

\begin{tabular}{|c|c|c|c|c|c|c|c|c|}
\hline \multirow[b]{2}{*}{ Crop } & \multirow{2}{*}{$\begin{array}{l}\text { Tuber yield } \\
\text { (t/ha) }\end{array}$} & \multicolumn{3}{|c|}{ Uptake (kg/ha) } & \multirow{2}{*}{$\begin{array}{l}\text { Farmyard manure } \\
(\mathrm{t} / \mathrm{ha})\end{array}$} & \multicolumn{3}{|c|}{$\begin{array}{l}\text { Recommended } \\
\text { dose }(\mathrm{kg} / \mathrm{ha})\end{array}$} \\
\hline & & $\mathrm{N}$ & $\mathrm{P}$ & $\mathrm{K}$ & & $\mathrm{N}$ & $\mathrm{P}$ & $\mathrm{K}$ \\
\hline Cassava & 30 & 180 & 22 & 160 & 12.5 & 100 & 50 & 100 \\
\hline Sweet potato & 14 & 34 & 6 & 47 & 5 & 50 & 25 & 50 \\
\hline $\begin{array}{l}\text { Elephant foot } \\
\text { yam }\end{array}$ & 36 & 122 & 31 & 176 & 25 & 100 & 50 & 150 \\
\hline Yams & 25 & 163 & 24 & 127 & 10 & 80 & 60 & 80 \\
\hline Taro & 17 & 119 & 18 & 157 & 12.5 & 80 & 25 & 80 \\
\hline Tannia & 20 & 125 & 37 & 187 & 25 & 80 & 50 & 150 \\
\hline Coleus & 26 & 106 & 13 & 107 & 10 & 60 & 60 & 100 \\
\hline Arrow root & 24 & 194 & 31 & 292 & 10 & 50 & 25 & 75 \\
\hline
\end{tabular}

Source: Mohan Kumar et al. (2000) 
reported that NUE of potatoes under low nitrogen input was higher than under high nitrogen input, and higher for late cultivars than for early cultivars.

\section{Conclusion}

There is an urgent need to broaden the food basket of the Sub-Saharan Africa by supporting root and tuber crops cultivation through boosting their capacity to adapt to climate change. Even though these crops have been neglected, there is evidence that the crops have greater adaptability to extreme climatic conditions and that they are more resilient to both biotic and abiotic stresses. Therefore, the suggested innovations and/or adaptation measures will help in enhancing their adaptability to climate change and also to enable them to produce more harvestable yields where major crops have failed.

\section{References}

Aidoo R (2009) An analysis of yam consumption patterns in Ghanaian urban communities. The School of Graduate Studies, Kwame Nkrumah University of Science and Technology, Kumasi. $\mathrm{PhD}$ Thesis. Access date 03 July 2017

Al-Jamal MS, Ball S, Sammis TW (2001) Comparison of sprinkler, trickle and furrow irrigation efficiencies for onion production. Agric Water Manag 46(3):253-266

Allem C (2002) The origins and taxonomy of cassava. In: Hillocks RJ, Thresh JM, Bellotti AC (eds) Cassava: biology, production and utilization. CABI Publishing, Wallingford, pp 1-16

Amer H (2011) Effect of irrigation method and quantity on squash yield and quality. Agric Water Manag 98:1197-1206

Arnau G, Abraham K, Sheela M, Chair H, Sartie A, Asiedu R (2010) Yams, in root and tuber crops. In: Bradshaw J (ed) Handbook of plant breeding, vol 7. Springer Science + Business Media, New York, pp 127-148

Asiedu R, Sartie A (2010) Crops that feed the world 1. Yams. Food Secur 2:305-315

Atakos V (2018) Next generation technologies: tackling climate change in agriculture. Retrieved from: https://cipotato.org/blog/next-generation-technologiestackling-climate-change-inagriculture/

Atakos V, Thiele G, Campos H, Friedmann M, Holmes H, Dudenhoefer D (2018) Next generation technologies: tackling climate change in agriculture. CIP. December 5, 2018

Augé M, Toler D, Saxton M (2015) Arbuscular mycorrhizal symbiosis alters stomatal conductance of host plants more under drought than under amply watered conditions: a meta-analysis. Mycorrhiza 25:13-24

Baybutt C, Hu L, Molteni A (2000) Vitamin A deficiency injures lung and liver parenchyma and impairs function of rat type II pneumocytes. J Nutr 130(5):1159-1165

Belachew T, Abera Y (2010) Response of maize (Zea mays L.) to tied ridges and planting methods at Goro, South eastern Ethiopia. Am Eur J Agron 3:21-24

Bennett B (2015) Smallholder cassava production and the cassava processing sector in Africa. Food Chain 5:1-3

Bentley JW, Andrade-Piedra J, Demo P, Dzomeku B, Jacobsen K, Kikulwe E, Ogero K (2018) Understanding root, tuber, and banana seed systems and coordination breakdown: a multistakeholder framework. J Crop Improv 32(5):599-621 
Birch J, Bryan G, Fenton B, Gilroy E, Hein I, Jones T, Prashar A, Taylor A, Torrance L, Toth K (2012) Crops that feed the world. Potato: are the trends of increased global production sustainable? Food Secur 4:477-508

Carsky J, Asiedu R, Cornet D (2010) Review of soil fertility management for yam-based systems in West Africa. Afr J Root Tuber Crops 8:1-17

Chen P, Rekha D, Arun B, Shen T, Lai A, Young C (2006) Phosphate solubilizing bacteria from subtropical soil and their tricalcium phosphate solubilizing abilities. Appl Soil Ecol 34(1):33-41

Ciais P, Sabine C, Bala G, Bopp L, Brovkin V, Canadell J, Chhabra A, DeFries R, Galloway J, Heimann M, Jones C, Quéré L, Myneni B, Piao S, Thornton P (2013) Carbon and other biogeochemical cycles. In: Stocker TF, Qin D, Plattner G-K, Tignor M, Allen SK, Boschung J, Nauels A, Xia Y, Bex V, Midgley PM (eds) Climate change 2013. The physical science basis. Contribution of working group I to the fifth assessment report of the intergovernmental panel on climate change. Cambridge University Press, Cambridge, UK/New York, pp 465-570

CIP (2017) Seed potato for Africa, [Accessed on April 12 2017] and available at http://cipotato.org/ seed-potato-for-africa/

CIP (2018) Potato minituber boom in Sub-Saharan Africa: tenfold increase in ten years - International Potato Center

Codd E (1985) Lamiaceae (Labiatae). In: Leistner OA (ed) Flora of Southern Africa. Volume 28, Part 4. Botanical Research Institute, Pretoria. 247pp

Coling C (1997) Effect of plastic film mulching on increasing potato yield: effect of plastic film mulching on increasing potato yield. Acta Agric Zhojangensis 9:83-86

Coursey G (1981) The interactions of yam and man. J Agric Tradit Bot Appl 1:5-21

Davies M, Labuschagne T, Koen E, Benesi M, Saka K (2008) Some properties of starches from cocoyam in Malawi. Afr J Food Sci 2:102-111

Davis C, Wolley N, Moreno A (1986) Multiple cropping with legumes starchy roots. Macmillan Publishing, New York, pp 133-160

Derpsch R, Friedrich T, Kassam A, Hongwen L (2010) Current status of adoption of no-till farming in the world and some of its main benefits. Int J Agric Biol Eng 3(1):1-25

Deschenes O, Greenstone M (2006) The economic impacts of climate change: evidence from agricultural output and random fluctuations in weather. Am Econ Rev 97:354-385

Development Fund (2011) Banking for the future: savings, security and seeds. Development Fund, Oslo. Accessed 29 Jan 2016

Dhankher OP, Foyer CH (2018) Climate resilient crops for improving global food security and safety. Plant Cell Environ 41(5):877-884

Don C (2007) No shortcuts in checking soil health. Agric Res. July 2007, at 4. Available at http:// www.ars.usda.gov/is/AR/archive/jul07/soil0707.pdf. Last visited 13 Nov 2008

Ennin A, Dapaah K, Asafu-Agyei N (2003) Land preparation for increased sweet potato production in Ghana. Paper presented at the 13th symposium of the international society for tropical root crops (ISTRC-World Branch). Held from 10th-14th November, 2003, Arusha, 14pp

Ennin SA, Otoo E, Tetteh FM (2009) Ridging, a mechanized alternative to mounding for yam and cassavaproduction. West Afr J Appl Ecol 15:1-8

EPA (2006) Solid waste management and greenhouse gases: a life-cycle assessment of emissions and sinks. 55

Erenstein O, Laxmi V (2008) Zero tillage impacts in India's rice-wheat systems: a review. Soil Tillage Res 100:1-14

FAO (2000) The state of food insecurity in the world 2000. ISBN 92-5-104479-1 Job No. X8200/E. $36 \mathrm{pp}$

FAO (2009) FAOSTAT statistical database. Rome (available at http://faostat.fao.org)

FAO (2011) The state of the world's land and water resources for food and agriculture (SOLAW). Managing systems at risk. FAO, Rome

FAO. FAOSTAT (2018) Food and Agriculture Organization of the United Nations (FAO), Rome. http://www.fao.org/faostat/ 
FAOSTAT (2017) Food and Agriculture Organization of the United Nations. Rome. http://apps. fao.org

FAOSTAT (Food and Agriculture Organization Data of Statistics) (2014) Food and Agriculture Organization Data of Statistics. One hundred fifty eight countries data base. http://faostat.fao. org $/$ site $/ 567 /$

Fernández R, Quiroga A, Zorati C, Noellemeyer E (2010) Carbon contents and respiration rates of aggregate size fractions under no-till and conventional tillage. Soil Tillage Res 109:103-109

Foereid B, Høgh-Jensen H (2004) Carbon sequestration potential of organic agriculture in northern Europe - a modelling approach. Nutrient Cycling in Agroecosystems 68(1):13-24

Graham W, Lam Y, Merckx V (2017) Plastomes on the edge: the evolutionary breakdown of mycoheterotroph plastid genomes. New Phytol 214:48-55

Greenland J, Gregory J, Nye H (1998) Land resources: on the edge of the Malthusian precipice. CAB International, Wallingford

Halvorson D, Weinhold J, Black L (2002) Tillage, nitrogen, and cropping system effects on soil carbon sequestration. Soil Sci Soc Am J 66:906-912

Helgason L, Walley L, Germida J (2010) No-till soil management increases microbial biomass and alters community profiles in soil aggregates. Appl Soil Ecol 46:390-397

Hillocks J, Thresh M, Bellotti C (2002) Cassava biology, production and utilization. CABI Publishing, Wallingford, p 2002

Hunziker L, Bönisch D, Groenhagen U, Bailly A, Schulz S, Weisskopf L (2015) Pseudomonas strains naturally associated with potato plants produce volatiles with high potential for inhibition of phytophthora infestans. Appl Environ Microbiol 81:821-830

IFA (1992) World fertilizer use manual. Publication of International Fertilizer Industry Association, Paris, pp 148-160

Intergovernmental Panel on Climate Change (2007) Climate change. In: Impacts, adaptation and vulnerability. Contribution of working group II to the fourth assessment report of the intergovernmental panel on climate change. Cambridge University Press, Cambridge, UK. 976pp

International Plant Genetic Resources Institute, (IPGRI) (2000) Enhancing the contribution of neglected and under-utilized species to food security, and to incomes of the rural poor. IPGRI, Rome

Jarvis A, Ramirez-Villegas J, Campo H, Navarro-Racines C (2012) Is cassava the answer to African climate change adaptation? Trop Plant Biol 5:9-29

Jha A, Saxena J, Sharma V (2013) Investigation on phosphate solubilization potential of agricultural soil bacteria as affected by different phosphorus sources, temperature, salt and pH. Commun Soil Sci Plant Anal 44:2443-2458

Jones B, Wendt W (1994) Contribution of soil fertility research to improved maize production by smallholders in eastern and southern Africa. In: Proceedings of the fourth Eastern and Southern Africa regional maize conference $2-14$

Khan MS, Zaidi A, Wani PA (2009) Role of phosphate solubilizing microorganisms in sustainable agriculture-a review. In: Sustainable agriculture (pp. 551-570). Springer, Dordrecht

Kintché K, Hauser S, Mahungu M, Ndonda A, Lukombo S, Nhamo N (2017) Cassava yield loss in farmer fields was mainly caused by low soil fertility and suboptimal management practices in two provinces of the Democratic Republic of Congo. Eur J Agron 89:107-123

Kivuva M, Yencho G, Sibiya J, Musembi G (2014) Assessment of production constraints and farmers' preferences for sweet potato genotypes. J Plant Breed Genet 02(01):15-29

Kumar A, Maurya BR, Raghuwanshi R, Meena VS, Islam MT (2017) Co-inoculation with Enterobacter and Rhizobacteria on yield and nutrient uptake by wheat (Triticum aestivum L.) in the alluvial soil under indo-gangetic plain of India. J Plant Growth Regul 36(3):608-617

Kumwenda F (1999) The role of animal traction in soil water conservation tillage practices among smallholder farmers in Malawi. In: Kaumbutho PG, Simalenga TE (eds) Conservation tillage with animal traction. A resource book of the Animal Traction Network for Eastern and Southern Africa (ATNESA), Harare. 173pp

Leihner D (1983) Management and evaluation of intercropping systems with cassava. CIAT, Cali 
Malik A, Sanghmitra S, Javed A (2011) Chemical vs. organic cultivation of medicinal and aromatic plants: the choice is clear. Int J Med Arom Plants 1(1):5-13

Marbun S, Sembiring M, Bintang (2015) Phosphate solubilizing microbe and organic matter application to increase P uptake and potatos growth at andisol impacted Sinabung Mountain Eruption. J Agroekoteknol 4:1651-1658. (In Indonesian)

Marques M (2015) Bacterial endophytes of sweet potato tuberous roots affected by the plant genotype and growth stage. J Appl Microbiol 96:273-281

Miyashita K, Tanakamaru S, Maitani T, Kimura K (2005) Recovery responses of photosynthesis, transpiration and stomatal conductance in kidney bean following drought stress. Environ Exp Bot 53:205-214

MoALF (2019) National root and tuber crops development strategy 2019-2022. Retrieved 12 November 2020, from https://www.kilimo.go.ke/wp-content/uploads/2019/10/Roots-andTuber-Crops-Strategy-2019-2022.pdf

Mohan Kumar CR, Nair M, George J, Ravindran S, Ravi V (2000) Production technology of tuber crops. Central Tuber Crops Research Institute, Thiruvananthapuram, p 174

Monneveux P, Ramírez A, Pino T (2013) Drought tolerance in potato (S. tuberosum L.): can we learn from drought tolerance research in cereals? Plant Sci 205:76-86

Morton F (2007) The impact of climate change on smallholder and subsistence agriculture. Proc Natl Acad Sci USA 104(50):19680-19685

Mostaghimi S, Gidley M, Dillaha TA, Cooke A (1994) Effectiveness of different approaches for controlling sediment and nutrient losses from eroded land. J Soil Water Conserv 49(6):615-620

Motsa NM, Modi T, Mabhaudhi T (2015) Sweet Potato (ipomoea Batatas L.) As a Drought Tolerant and Food Security Crop. S Afr J Sci 111(11/12):8. Art. \#2014-0252

Nath R, Chattopadhyay A, Kundu CK, Majumder A, Islam Sk J, Gunri S (2007) Production potential of sweet potato in the Red and Laterite ecosystem of West Bengal. J Root Crops 33:97-103

Nayar R, Suja G (2004) Production potential of root and tubers in multiple cropping systems involving plantation crops. J Root Crops 30(2):93-100

Naylor L, Falcon P, Goodman M, Jahn M, Sengooba T, Tefera H (2004) Biotechnology in the developing world: a case for increased investments in orphan crops. Food Policy 29:15-44

Nieto CO (2016) Nitrogen use efficiency in potato: an integrated agronomic, physiological and genetic approach. Doctoral dissertation, Wageningen University

Nugroho W (1994) Klasifikasidan Pemetaan Semi Detail Tanah Berkembangdari Abu Volkanikberdasarkan Sistem Taksonomi Tanah di Desa Candikuning, Baturiti, Tabanan. Skripsi. Jurusan Tanah, Fakultas Pertanian Universitas Udayana. pp 75

Nweke FI, Spencer DSC, Lynam JK (2002) The cassava transformation: Africa's best kept secret, Michigan State University Press, East Lansing, USA. pp 273

O'Sullivan N, Ernest J (2007) Nutrient deficiencies in lesser yam (Dioscorea esculenta) characterized using constant-water table sand culture. J Plant Nutr Soil Sci 170(2):273-282

Okigbo N (1989) New crops for food industry: the roots and tuber in tropical Africa. In: New crops for food industry. G.E. Weekens et al, Chapman and Wall/London, pp 123-134

Onwueme C, Sinha D (1991) Field crop production in tropical Africa: principles and practice. Technical Centre for Agriculture and Rural Cooperation, Ede. ISBN-13: 9789290810865 , pp 267-275

Onyeka J (2014) Status of cocoyam (Colocasia esculenta and Xanthosoma spp.) in west and central Africa: production, household importance and the threat from leaf blight. CGIAR Research Program on Roots, Tubers and Bananas (RTB)

Ossom M, Pace F, Rhykerd L, Rhykerd L (2001) Effect of mulch on weed infestation, soil temperature, nutrient concentration and tuber yield in Ipomoea batatas in Papua New Guinea. Trop Agric 78:144-151

Pinto J, Onwueme B (2000) Food values of breadfruit, taro leaves, coconut and sugar cane. FAO. Plant production and protection paper 126. FAO, Rome

Pruski (2001) Micropropagation technology in early phases of commercial seed potato production. $\mathrm{PhD}$ Thesis, Wageningen University, Wageningen, p 166

Purseglove W (1972) Monocotyledons (tropical crops S). London: Longman Group Ltd 
Purseglove W (1975) Tropical crop monocotyledonous. Longman Group, Britain

Ramanatha V, Matthews J, Eyzaguirre B, Hunter D (2010) The global diversity of taro: ethnobotany and conservation. Biodiversity International, Rome

Robert W, Cartwhight B (2006) Potato production. Oklahoma Cooperative Extension Service, Stillwater

Rudrappa U (2013) Yams nutrition facts and health benefits. http://www.nutrition-and you.com/ yams.html

Rykaczewska K (2013) The impact of high temperature during growing season on potato cultivars with different response to environmental stresses. Am J Plant Sci 04:2386-2393. https://doi.org/ 10.4236/ajps.2013.412295

Sagoe R (2006) Climate change and root crop production in Ghana. Crops Research Institute, Kumasi

Sangakkara R, Attanayake B, Gajanayake N, Bandaranayake R (2004) Impact of mulches on growth and yields of cassava and sweet potato in tropical Asia. In: Proceedings of the 4th international crop science congress, Brisbane, 26 September-1 October 2004

Sarma A, Dutta T, Sarma A (1999) Effect of mulching technique with black plastic film (25 u) on potato crop under rainfed condition. Crop Res 18:383-386

Schüßler H, Gehrig H, Schwarzott D, Walker C (2001) Analysis of partial Glomales SSU rRNA gene sequences: implications for primer design and phylogeny. Mycol Res 105:5-15

Sefa-Dedeh S, Kofi-Agyir E (2002) Starch structure and some properties of cocoyam (Xanthosoma sagittifolium and Colocacia esculentum) starch and raphides. Food Chem 79:435-444

Shetto M (1999) Tillage practices and soil conservation measures in Tanzania. http://www.fao.org/ ag/ages/3ero/Harare/partii/19Sheto.htm

Sieverding E (1991) Vesicular-arbuscular mycorrhiza management in tropical agrosystems. Deutche Gesellschaft für Technische Zusammenarbeit (GTZ), Eschborn. 371p

Sombroek WG, Gommes LR (1997) Changement de climat - Agriculture. In: FAO (ed) Changements du Climat et Production Agricole. FAO, Rome, p 472

Spooner DM, McLean K, Ramsay G (2005) A single domestication for potato based on multi-locus amplified fragment length polymorphism genotyping. Proc Natl Acad Sci 102:14694-14699

Sriom S, Mishra P, Rajbhar P, Singh D, Singh K, Mishra K (2017) Effect of different levels of nitrogen on growth and yield in potato (Solanum Tuberosum L.) Cv. Kufri Khyati. Int J Curr Microbiol App Sci 6:1456-1460. https://doi.org/10.20546/ijcmas.2017.608.428

Stokes C, Howden M (2010) Adapting agriculture to climate change: preparing australian agriculture, forestry, and fisheries for the future. CSIRO Publishing, Collingwood

Suyamto, Howeler H (2001) Cultural practices for soil erosion control in cassava-based cropping systems in Indonesia. In: Barker DH, Watson A, Sombatpanit S, Northcutt B, Maglinao AR (eds) In International Erosion Control Association, Ground and water Bioengineering for the Asia-Pacific Region. Science Publishers, Enfield, New Hampshire

Tailor J, Joshi H (2014) Harnessing plant growth promoting rhizobacteria beyond nature: a review. J Plant Nutr 37:1534-1571

Tshisola N (2014) Improved potato (Solanum tuberosum L.) seed production through aeroponics. MSc thesis, Stellenbosch University

Udo J, Ndon A, Asuquo E, Ndaeyo U (2005) Crop production techniques for the tropics. Concept Publications, Lagos

Ukom N, Ojimelukwe C, Okpara A (2009) Nutrient composition of selected sweet potato (Ipomoea batatas (L.) Lam) varieties as influenced by different levels of nitrogen fertilizer application. Pak J Nutr 8(11):1791-1795

Unger W (1994) Managing agricultural residues. Lewis Publishers, Boca Raton. 448pp

Uroz S, Calvaruso C, Turpault P, Frey-Klett P (2009) Mineral weathering by bacteria: ecology, actors and mechanisms. Trends Microbiol 17:378-387

Vernooy R, Sthapit B, Galluzzi G, Shrestha P (2014) The multiple functions and Services of Community Seedbanks. Resources 4(3):636-656

Vessey K (2003) Plant growth-promoting rhizobacteria as biofertilizers. Plant Soil 255:571-586

Wiebe K (2015) Strategic foresight: long-term projections from IFPRI, GFSF and AgMIP. Presented at the 12th Meeting of the Independent Science \& Partnership Council held in Rome, 16 September 2015 
Wiyo A, Kasomekerab M, Feyen J (1999) Effect of tied-ridging on soil water status of a maize crop under Malawi conditions. Agric Water Manag 45(2000):101-121

Woolfe A (1992) Sweet potato, an untapped food resource. Cambridge University Press, Cambridge, UK

Open Access This chapter is licensed under the terms of the Creative Commons Attribution 4.0 International License (http://creativecommons.org/licenses/by/4.0/), which permits use, sharing, adaptation, distribution and reproduction in any medium or format, as long as you give appropriate credit to the original author(s) and the source, provide a link to the Creative Commons license and indicate if changes were made.

The images or other third party material in this chapter are included in the chapter's Creative Commons license, unless indicated otherwise in a credit line to the material. If material is not included in the chapter's Creative Commons license and your intended use is not permitted by statutory regulation or exceeds the permitted use, you will need to obtain permission directly from the copyright holder.

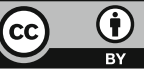

